\title{
PENGEMBANGAN MEDIA PEMBELAJARAN GAME EDUKASI BERBASIS ANDROID PADA MATA PELAJARAN EKONOMI KELAS X IPS SMA NEGERI 1 BANGKALAN
}

\author{
Karimatin Nurisa \\ Program Studi Pendidikan Ekonomi, Fakultas Ekonomi, Universitas Negeri Surabaya \\ e-mail: Karimatin29@gmail.com \\ Muhammad Abdul Ghofur \\ Program Studi Pendidikan Ekonomi, Fakultas Ekonomi, Universitas Negeri Surabaya \\ e-mail: muhammadghofur@unesa.ac.id
}

\begin{abstract}
Abstrak
Pembelajaran di dalam kelas yang menciptakan suasana menyenangkan akan berdampak positif bagi siswa untuk menambah rasa ingin tahu, sebuah game edukasi berbasis yang diharapkan menciptakan suasana belajar yang menyenangkan dan hasil belajar yang di dapat dengan baik. Pada penelitian ini memiliki tujuan untuk melihat bagaimana meningkatkan hasil belajar dengan menggunakan media pembelajaran game edukasi berbasis android terhadap hasil belajar peserta didik kelas X SMA Negeri 1 Bangkalan. Penelitian ini menggunakan penelitian pengembangan atau Research and Development (R\&D) dengan model ADDIE yaitu Analysis (Analisis), Design (Desain), Development (Pengembangan), Implementation (Implementasi) dan Evaluation (Evaluasi). Desain Penelitian yang di pakai adalah One Group Pretest-Posttest Design Penelitian ini mengambil subjek peserta didik kelas X IPS untuk uji coba produk media pembelajaran game edukasi berbasis android. Hasil penelitian yang di dapat dari perolehan hasil validasi untuk mengetahui kelayakan media, hasil belajar dan respon siswa. Hasil dari penelitian ini menunjukkan bahwa validasi kelayakan media pada seluruh aspek memeroleh rata-rata presentase sebesar $100 \%$. Hasil validasi evaluasi memeroleh skor rata-rata 76,06 \%. Hasil respon siswa pada seluruh aspek memeroleh hasil rata-rata presentasen sebesar $97 \%$. Penelitian menunjukkan rata-rata pre-test 69,55; rata-rata post-test 83,7 . Uji paired sampel t-test posttest menunjukkan sig. (2-tailed) ,000 $(0,00)$ Hasil menunjukkan bahwa terdapat peningkatan antara pretest dan posttest $<0,05$ yaitu $0,00<0,05$. Berdasarkan hasil analisis uji paired sample t-test di atas, maka $\mathrm{H}_{\mathrm{a}}$ diterima dan $\mathrm{H}_{0}$ ditolakHal ini menunjukkan bahwa media pembelajaran Game Edukasi berbasis android sangat layak digunakan.
\end{abstract}

Kata Kunci: Game Edukasi berbais Android, Bank Sental, Hasil Belajar

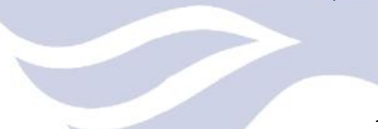

The Joyful Learning is expected to make students have more curiosity aboaut something, An educational-based game that is expected to create a fun learning atmosphere and learning outcomes that are obtained well. The purpose of this study is to see how to improve learning outcomes by using an Android-based educational game learning media on the learning outcomes of class X students of SMA 1 Bangkalan. This study uses research and development (R \& D) with the ADDIE model, namely Analysis, Design, Development, Implementation and Evaluation. The research design used is One Group PretestPosttest Design This study took the subject of students of class X IPS to test educational media products based on Android games. The research results obtained from the results of validation to determine the feasibility of the media, learning outcomes and student responses. The results of this study indicate that the validation of media feasibility in all aspects obtained an average percentage of $100 \%$. The evaluation validation results obtained an average score of $76.06 \%$. The results of student responses in all aspects obtained an average percentage of $97 \%$. Research shows an average pre-test of 69.55 ; post-test average 83.7. The paired test of the posttest t-test sample shows sig. (2-tailed), $000(0,00)$ The results show that there is an increase between pretest and posttest $<0.05$ which is $0.00<0.05$. Based on the results of the paired sample t-test analysis above, $\mathrm{Ha}_{\mathrm{a}}$ is accepted and $\mathrm{H}_{0}$ is rejected. This shows that the Android-based Educational Game learning media is very feasible to use.

Keywords: Android Based Educational Game, Central Bank, Learning Outcomes 


\section{PENDAHULUAN}

Teknologi informasi yang ada di era sekarang ini menguasai dunia pendidikan dalam menyampaikan informasi pembelajaran. Hal yang paling menonjol dalam perubahan sistem pendidikan di Indonesia ialah perubahan kurikulum. Salah satunya dengan menciptakan media pembelajaran game edukasi berbasis android sebagai pendukung dalam menyampaikan informasi pelajaran di dalam kelas yang penggunaannya dapat diakses dengan menggunakan smarthphone android yang dimiliki oleh peserta didik dibantu dengan fasilitas internet yang sudah disediakan oleh sekolah.

Pembelajaran pada Mata Pelajaran Ekonomi di SMA Negeri 1 Bangkalan dengan materi Bank Sentral, Sistem Pembayaran dan Alat Pembayaran dengan perolehan nilai hasil belajar siswa yang masih rendah. Hal ini terjadi karena kurangnya konsentrasi siswa di dalam pelajaran, kurang adanya komunikasi dengan bertanya maupun berpendapat dan keterbatasan dalam menyampaikan informasi materi pembelajaran dari berbagai sumber, dengan adanya hubungan seorang guru dan siswa yang diharapkan dapat menjadikaan sebuah hubungan komunikasi yang baik dalam penyampaian informasi pelajaran di dalam kelas. Kualitas peserta didik dapat dilihat dari penggunaan model pembelajaran pada saat berlangsungnya proses belajar mengajar di dalam kelas, namun hal ini bukan menjadikan satu-satunya faktor dalam tingkat keberhasilan peserta didik. Melainkan lebih memperhatikan proses penyampaian pembelajaran terhadap peserta didik menghindari terjadinya kebosanan. Menggunakan media pembelajaran yang modern untuk menciptakan daya tarik siswa terhadap penyampaian informasi pembelajaran. dengan media pembelajaran yang modern secara otomatis akan menarik siswa dalam antusias belajar sehingga mempunyai dampak positif yaitu mempengaruhi hasil belajar peserta didik.

Berdasarkan hasil yang di dapat pada saat melaksanakan wawancara dengan guru mata pelajaran ekonomi pada saat melakukan studi pendahuluan, salah satu materi pembelajaran ekonomi yaitu Bank Sentral, Sistem Pembayaran dan Alat Pembayaran merupakan materi dengan menerapkan peserta didik untuk terjun langsung dalam memahami materi secara maksimal sehingga peserta didik dapat mempelajarinya dengan praktek langsung di lapangan, pada kenyataannya dengan keterbatasan waktu dan tidak memungkinkan peserta didik untuk mempelajari materi bank sental, sistem pembayaran dan alat pembayaran di lapangan. Hal tersebut disebabkan karena adanya keterbatasan waktu juga perijinan dari sekolah.
Hasil observasi lanjutan, peneliti menemukan fakta pada saat penyampaian informasi pembelajaran di kelas, guru menggunkan model pembelajaran langsung yaitu metode ceramah, dan penggunaan media media adalah powerpoint dengan keterbatasan fasilitas yang tersedia di sekolah sehingga tidak selamanya dalam pelaksanaan proses belajar mengajar di kelas menggunakan alat bantu media pembelajaran. Hal tersebut dapat dibantu dengan media yang praktis dan edukatif dengan penggunaan smarthphone android saat proses belajar mengajar membuat peserta didik merasa penyamian informasi pembelajaran ekonomi monoton dan membosankan pada saat proses pembelajaran yang berlangsung. Sehingga keadaan peserta didik tidak memperhatikan pelajaran untuk bermain smarthphone masing-masing. Hal tersebut memilki dampak pada proses pembelajaran berlangsung dengan tidak maksimal di dalam kelas, dibuktikan dengan rendahnya hasil belajar peserta didik yang masih jauh dengan ketentuan KKM sekolah, yaitu delapan puluh (80).

Permasalahan tersebut di dapat dari kelemahan media yang digunakan sebelumnya dan media dengan keterbatasan fasilitas alat pembelajaran di kelas untuk menunjang proses pembelajaran maka diperlukan media tambahan lain yang dapat mendukung ketuntasan belajar siswa dengan media pembelajaran informasi pendidik. Melihat fenomena di lapangan peserta didik di SMA Negeri 1 Bangkalan, $90 \%$ memiliki Handphone pintar. Handphone pintar dengan segala macam kegunaannya bukan hanya komunikasi dan bermain, melainkan sebagai media pendukung pembelajaran untuk menunjang proses belajar mengajar. dengan menggunakan pembelajaran modern platform android yang dapat dijadikan sebuah alternatif media untuk menunjang proses berlangsungnya penyampaian informasi pembelajaran di kelas maupun tidak dengan jam pelajaran di kelas siswa dapat belajar dengan sendiri. karena aplikasi berbasis android merupakan media yang cocok untuk di terapkan sebagai pada era sekarang sebagai alat bantu guru pada proses pembelajaran yang modern.

Pada pilihan pengembangan yang mendukung untuk media tambahan yang digunakan agar menunjang tujuan pembelajaran adalah pengembangan pembelajaran dengan game. Munir (2017, p. 81) saat ini game merupakan sebuah sistem dimana pemain terlibat di dalam suatu konflik yang sudah di buat bahkan sudah di tentukan dengan adanya aturan dengan menghasilkan penentuan hasil yang sudah terukur.

Semakin adanya kemajuan di era modern saat ini game merupakan media pembelajaran yang menunjang seiring kemajuan teknologi. Menurut Parwanti (2015)“a game is an activity in which participants follow 
prescribed rules that differ from those of real life as they strive to attain a challenging goal".

Penelitian dilakukan oleh Defrianto, Kridalukmana \& Windasari (2015), menyatakan bahwa Media Pembelajaran Game Edukasi berbasis Android dengan hasil $83 \%$ jawaban benar dari responden dan dapat dikatakan game edukasi layak untuk digunakan, yang artinya lebih $80 \%$ hasil dari penerapan game edukasi mengatakan setuju.

Menurut Pramuditya, Noto \& Purwono (2018) pada penelitiannya juga menyatakan secara keseluruhan penilaian uji coba terbatas diperoleh presentase sebesar $97,12 \%$. Kesimpulan penggunaan game edukasi pada pembelajaran matematika berbasis android dapat digunakan dan mudah dalam menerapkannya. Dapat di lihat dari hasil rata-rata perolehan presentase kemampuan peserta tinggi dengan nilai $94,3 \%$, siswa dengan kemampuan sedang $92,2 \%$, dan perolehan nilai siswa kemampuan rendah sebesar $92,2 \%$. Pembelajaran yang di terima oleh kelas XI IPS di SMA mata pelajaran materi akuntansi rata-rata yang di dapat 4,19 termasuk kategori dapat digunakan, proses game edukasi ini dapat disebar luaskan menjadi satu alternatif belajar peserta didik pada kelas XI IPS SMA di berbagai sekolah di indonesia.

Teori Kontruktivisme mengenalkan bahwa belajar merupakan kegiatan manusia dalam membangun maupun menciptakan pengetahuannya, dalam teori belajar yang dijelaskan oleh David Ausabel yang sangat dekat dengan pernyataan teori kontruktivisme (Sani, 2016, p. 15) . Dengan memberikan pelajaran kepada siswa dalam mempelajari pentingnya pengalaman, fenomena, dan fakta-fakta dalam sebuah pengertian yang sudah dimilki maka disitulah terjadi pembelajaran yang bermakna. Selain itu terdapat kejelasan stabilitas dalam menggunkan game edukasi berbasis android dengan bekal pengetahuan yang dimilki maka siswa dapat menjadikan sebuah proses belajar.

Penelitian dari pengembangan media berupa game edukasi berbasis platform android ini dengan tujuan dapat meningkatkan hasil belajar siswa dalam mata pelajaran ekonomi pada materi Bank sentral, Sistem pembayaran dan Alat pembayaran yang dapat diaplikasikn sebagai media pendukang dalam penyampaian informasi belajar di dalam kelas meskipun tidak terjun secara langsung dalam praktek di lapangan. Media pembelajaran menggunakan game edukasi berbasis android dapat dilihat apabila penggunaannya mendapatkan respon siswa siswa pada saat uji coba dalam pembelajaran.

\section{METODE}

Jenis penelitian yang digunakan yaitu Research and Development (R\&D) dengan model penelitian ADDIE yaitu Analysis (Analisis), Design (Desain),
Development (Pengembangan), Implementation (Implementasi) dan Evaluation (Evaluasi). Penelitian ini dilakukan di SMA Negeri 1 Bangkalan yang terletak pada Jl. Pemuda Kaffa No. 10 Bangkalan, Kabupaten Bangkalan Jawa Timur pada tahun ajaran 2017/2018.

Instrumen pengumpulan data menggunakan hasil pretest dan posttest untuk mengetahui hasil dari uji coba produk, selain itu dilakukan validasi dengan para ahli, materi, media dan evaluasi untuk mengetahui produk yang dikembangkan.

Data yang dikumpulkan kemudian di analisis lembar validasi menggunakan skala linkert untuk mengetahui presentase kelayakan produk, hasil belajar, dan respon siswa dianalisis menggunakan skala guttman, dan hasil belajar dengan menggunakan persentase ketuntasan klasikal. Selian itu pengembangan media pembelajaran game edukasi berbasis android menggunakan dokumentasi, tes dan observasi yang digunakan untuk pengumpulkan data-data pada proses penelitian ini. Teknik analisis data menggunakan peresentase ketuntasan klasikal, dan berbagai uji menggunakan SPSS yaitu normalitas, dan paired sample t-test.

\section{HASIL DAN PEMBAHASAN}

\section{ADDIE}

Penelitian ini menghasilkan sebuah produk yaitu sebuah game edukasi yang berjudul "Treasure Of Bank Challenge" yng dilengkapi dengan materi dan latihan soal. Pada proses pembuatan produk game edukasi ini melalui beberapa tahapan sehingga dapat diujicobakan kepada siswa .

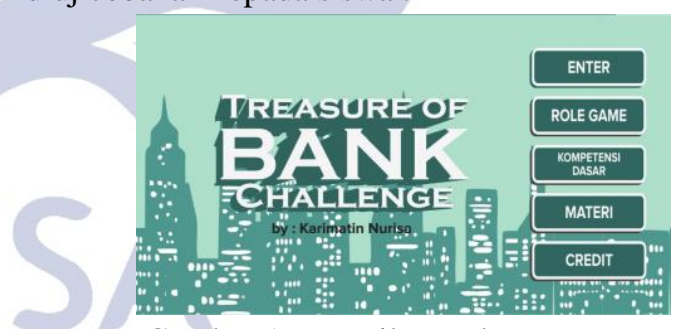

Gambar 1. Tampilan Halaman Utama

Sumber: diolah oleh Peneliti (2019)

Media yang dihasilkan di desain dengan layout landscape. Pada tampilan halaman utama terdapat buton Enter, Role Game, Kompetensi Dasar, Materi, Credit.

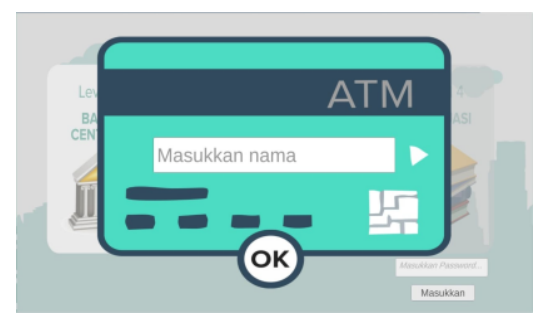

Gambar 2. Tampilan Papan Nama Pemain

Sumber: diolah oleh Peneliti (2019) 
Pada tampilan papan nama pemain mempunyai fungsi untuk penyimpanan nilai pada akhir game secara otomatis.

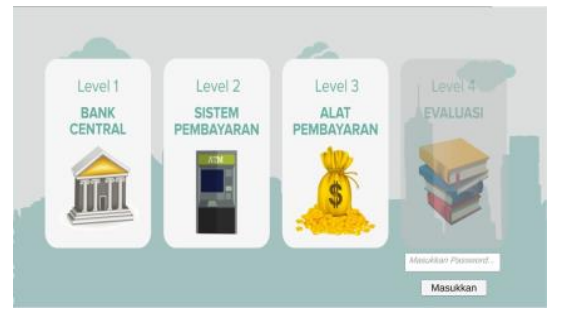

Gambar 3. Tampilan Pilihan Level Game Sumber: diolah oleh Peneliti (2019)

Pada tampilan game terdapat 3 pilihan level game dan salah satunya adalah evaluasi.

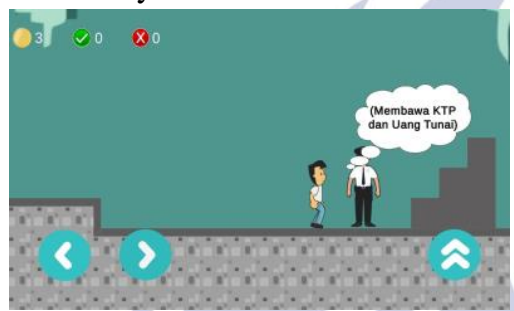

Gambar 4. Tampilan Game

Sumber: diolah oleh Peneliti (2019)

Pada tampilan level game di desain beberapa icon diantaranya icon koin untuk mengetahui berapa jumlah koin yang di kumpulkan, icon salah untuk mengetahui berapa soal yang di jawab salah dan icon benar untuk mengetahui soal yang di jawab benar, dan dilengkapi juga dengan tombol maju, tombol mundur, serta tombol untuk melompat.

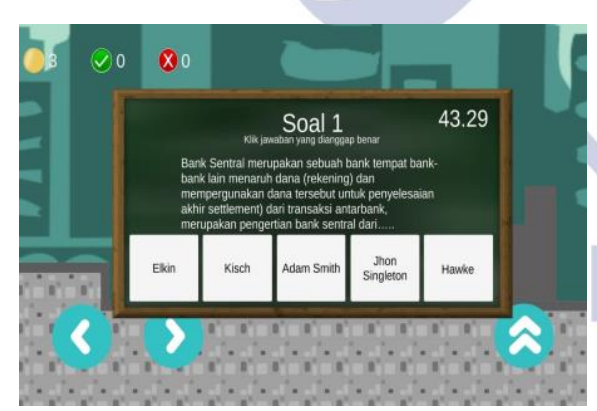

Gambar 5. Tampilan soal pada game

\section{Sumber: diolah oleh Peneliti (2019)}

Tampilan soal akan muncul setelah melalui dialog-dialog pemain.

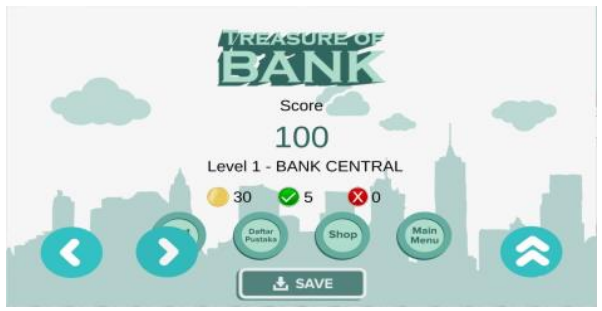

Gambar 6.Tampilan Skor Akhir Permainan Sumber: diolah oleh Peneliti (2019)

Tampilan skor akan muncul setelah permainan pada level berakhir, terdapat 5 icon diantaranya next untuk melanjutkan pada level selanjutnya, daftar pustaka, shop untuk membeli jawaban yang salah pada saat permainan, main menu untuk kembali ke menu awal game, dan yang terakhir save untuk menyimpan hasil nilai yang di peroleh secara otomatis ke galeri handphone.

\section{Kelayakan Game Edukasi}

Kelayakan media yang dikembangkan dinilai oleh ahli -ahli di bidangnya dan guru. Aspek yang dinilai yaitu dari segi materi, evaluasi, dan media. Pada penelitian terdahulu tentang pengembangan game edukasi siswa mengayatakan bahwa sangat layak.

Kelayakan Game Edukasi berbasis Android diperoleh melalui perolehan validasi oleh ahli materi dan evaluasi Retno Mustika Dewi, S.Pd., M.Pd. dan ahli media Alim Sumarno S.Pd., M.Pd. dengan perolean hasil sebagai berikut:

\section{Tabel 1 Hasil Validasi Oleh Para Ahli}

\begin{tabular}{cccc}
\hline Aspek & $\begin{array}{c}\text { Hasil } \\
\text { Keseluruhan }\end{array}$ & $\%$ & Kategori \\
\hline $\begin{array}{c}\text { Ahli } \\
\text { Materi }\end{array}$ & 46 & 78 & Layak \\
\hline $\begin{array}{c}\text { Ahli } \\
\text { Evaluasi }\end{array}$ & 42 & 79,6 & Layak \\
\hline $\begin{array}{c}\text { Ahli } \\
\text { Media }\end{array}$ & 90 & 100 & $\begin{array}{c}\text { Sangat } \\
\text { Layak }\end{array}$ \\
\hline$\Sigma$ Total & $\mathbf{1 7 8}$ & $\mathbf{8 5 , 8 6}$ & $\begin{array}{c}\text { Sangat } \\
\text { Layak }\end{array}$ \\
\hline
\end{tabular}

Sumber: data diolah peneliti (2019)

Berdasarkan hasil pada tabel penilaian ahli materi mendapatkan presentase sebesar $78 \%$. Oleh karena itu pengembangan Game Edukasi berbasis Android ini dinyatakan layak dari ahli materi. Komponen yang terdapat dalam penilaian ahli materi terdiri yaitu isi dan penyajian.

Komponen dari ahli evaluasi diperoleh persentase sebesar 76,9 ahli media sebesar $100 \%$. Hasil rata-rata keseluruhan dari ketiga aspek 
diperoleh presentase sebesar $85,86 \%$ kategori sangat layak sesuai jika seluruh aspek komponen mencapai $\geq$ $61 \%$

Pada penelitian sebelumnya yang dilakukan oleh Penelitian dilakukan oleh Defrianto, Kridalukmana \& Windasari (2015), menyatakan bahwa Media Pembelajaran Game Edukasi berbasis Android dengan hasil $83 \%$ jawaban benar dari responden dan dapat dikatakan game edukasi layak untuk digunakan , yang artinya lebih dari $80 \%$ hasil mengatakan setuju.

\section{Hasil Angket Respon Siswa}

Hasil yang diperoleh dari respon siswa dalam penggunaan media pembelajran Game Edukasi berbasis platform android diperoleh dari hasil analisis uji coba pada 20 peserta didik kelas X IPS 1 SMA Negeri 1 Bangkalan sebagai responden. Hasil skor yang diisi dari hasil respon peserta didik dianalisis dengan skala Guttman dengan skor 1 dengan pilihan "YA" dan skor 0 untuk pilihan "TIDAK" berikut hasil skor dari analisis pesdrta didik sebgai responden Uji coba terbatas pada media pembeljaran Game Edukasi berbasis Android.

Tabel 4 hasil angket respon siswa

\begin{tabular}{|c|c|c|c|c|}
\hline Aspek & Ya & Tidak & $\%$ & Kategori \\
\hline 1 & 20 & 0 & 100 & $\begin{array}{l}\text { sangat } \\
\text { layak }\end{array}$ \\
\hline 2 & 18 & 2 & 90 & $\begin{array}{l}\text { sangat } \\
\text { layak }\end{array}$ \\
\hline 3 & 20 & 0 & 100 & $\begin{array}{c}\text { sangat } \\
\text { layak }\end{array}$ \\
\hline 4 & 19 & 1 & 95 & $\begin{array}{c}\text { sangat } \\
\text { layak }\end{array}$ \\
\hline 5 & 20 & 0 & 100 & $\begin{array}{c}\text { sangat } \\
\text { layak }\end{array}$ \\
\hline 6 & 20 & 0 & 100 & $\begin{array}{c}\text { sangat } \\
\text { layak }\end{array}$ \\
\hline 7 & 19 & 1 & 95 & $\begin{array}{c}\text { sangat } \\
\text { layak }\end{array}$ \\
\hline 8 & 19 & 1 & & $\begin{array}{c}\text { sangat } \\
\text { layak }\end{array}$ \\
\hline 9 & 19 & 1 & 95 & $\begin{array}{c}\text { sangat } \\
\text { layak }\end{array}$ \\
\hline 10 & 20 & 0 & 100 & $\begin{array}{c}\text { sangat } \\
\text { layak }\end{array}$ \\
\hline $\begin{array}{l}\text { Total } \\
\text { skor }\end{array}$ & 194 & 6 & 97 & $\begin{array}{c}\text { sangat } \\
\text { layak }\end{array}$ \\
\hline
\end{tabular}

Sumber: Data diolah peneliti (2019)

Perolehan hasil respon siswa pada tabel dapat dilihat bahwa peserta didik sangat branantusias dalam media pembelajaran Game dukasi berbasis Android dengan hasil 97\%, hasil respon siswa.

Dari hasil perhitungan yang diperoleh dengan nilai $97 \%$ yang berarti termasuk dalam kategori peserta didik memilki ketertarikan media Sangat Baik terhadap pembelajaran menggunakan media game
Edukasi berbasis android dan hal ini didukung dengan perolehan hasil uji coba posttest peserta didik dengan hasil 83,7 dengan hasil yang diperoleh malampaui diatas KKM 80.

\section{Hasil Belajar Siswa}

Mengetahui hasil belajar siswa pada saat diberikan Pretest Posttest. Tes melalui 2 tahap dalam uji coba. Uji coba pertama Pretest dan yang kedua Posttest pada kelas X IPS 1 dengan jumalah 20 peserta didik dilakukan dengan uji coba terbatas. Data dari hasil Pretest dan Posttest yang dikerjakan siswa kemudian dinilai.

Tabel 5 Hasil Pretest Siswa

\begin{tabular}{ccc}
\hline Nilai & Frekuensi & Keterangan \\
\hline $50-55$ & 2 & TidakTuntas \\
\hline $56-60$ & 0 & TidakTuntas \\
\hline $61-65$ & 0 & TidakTuntas \\
\hline $66-70$ & 7 & TidakTuntas \\
\hline $71-75$ & 10 & TidakTuntas \\
\hline $76-80$ & 0 & Tuntas \\
\hline $81-85$ & 0 & Tuntas \\
\hline $86-90$ & 1 & Tuntas \\
\hline $91-95$ & 0 & Tuntas \\
\hline $96-100$ & 0 & Tuntas \\
\hline Jumlah & 20 & \\
\hline
\end{tabular}

\section{Sumber: Data diolah peneliti (2019)}

Tabel hasil belajar siswa pretest terdapat 20 siwa dan 1 siswa yang mempunyai nilai ketuntasan belajar (>80). Dilihat dari presentase ketuntsan belajar dengan nilai pretest sebesar 5\% karena dari 20 peserta didik hanya 1 yang mendapatkan nilai KKM (>80) Hasil belajar siswa dari uji coba Posttest dapat dilihat dari hasil berikut:

Tabel 6 Hasil Posttest Siswa

\begin{tabular}{ccc}
\hline Nilai & Frekuensi & Keterangan \\
\hline $50-55$ & 0 & Tidak Tuntas \\
\hline $56-60$ & 0 & Tidak Tuntas \\
\hline $61-65$ & 0 & Tidak Tuntas \\
\hline $66-70$ & 1 & Tidak Tuntas \\
\hline $71-75$ & 1 & Tidak Tuntas \\
\hline $76-80$ & 8 & Tuntas \\
\hline $81-85$ & 0 & Tuntas \\
\hline $86-90$ & 6 & Tuntas \\
\hline $91-95$ & 4 & Tuntas \\
\hline $96-100$ & 0 & Tuntas \\
\hline Jumlah & 20 & \\
\hline
\end{tabular}

\section{Sumber: Data diolah peneliti (2019)}

Diketahui dari tabel hasil belajar siswa posttest terdapat 20 peserta didik dan 18 siswa memiliki nilai belajar siatas KKM (>80). Perolehan hasil yang di dapat dari presentase ketuntasan hasil belajar posttest sebesar $90 \%$, sehingga hasil belajar peseerta didik disimpulkan terdapat kenaikan.

\section{PENUTUP}

\section{Simpulan}


Terdapat perbedaan hasil belajar sebelum menerapkan media pembelajaran sebagai media pendukung penyampaian informasi dengan sesudah menggunakan media game edukasi berbasis android pada peserta didikkelas X IPS SMA Negeri 1 Bangkalan. Perolehan nilai hasil belajar dengan nilai 69,55 dan meningkat sebesar $14,15 \%$ sehingga menjadi $83,7 \%$.

\section{Saran}

penelitian pengembangan ini bisa dijadikan alat bantu guru pengajar sebagai alternatif media penyampaian informasi belajar yang dapat mengaktifkan suasana belajar di dalam kelas dengan media pembelajaran yang modern dan media pembeljaran ini masih perlu ditingkatkan dan dikembangkan lagi menjadi media pembelajaran yang compatible sehingga menjadi media yang dapat diakses dalam tingkatan versi yang lebih baik dalam media pembelajaran.

\section{DAFTAR PUSTAKA}

Arikunto, S. (2013). Dasar - Dasar Evaluasi Pendidikan. (R. Damyanti, Ed.) (edisi 2). Jakarta: PT. Bumi Aksara.

Arsyad, A. (2014). Media Pembelajaran. (A. Rahman, Ed.). Jakarta: PT RAJA GRAFINDO JAKARTA.

Defrianto, D., Kridalukmana, R., \& Windasari, I. P. (2015). Pengembangan Permainan Edukatif Ragam Budaya Nusantara Berbasis Android. Jurnal Teknologi Dan Sistem Komputer, 3(3), 379. https://doi.org/10.14710/jtsiskom.3.3.2015.379-386

Munir, M. (2017). Pembelajaran Digital. (R. R. Firly \& A. S. Syukron, Eds.). Bandung: ALFABETA,cv.

Parwanti, M. (2015). PENINGKATAN KEAKTIFAN DAN HASIL BELAJAR IPS MELALUI PEMBELAJARAN KOOPERATIF MODEL PERMAINAN PADA SISWA SMPN 1 BANTARSARI CILACAP Parwanti,. Jurnal Pendidikan IPS, 2(1), 87-96.

Pramuditya, S. A., Noto, M. S., \& Purwono, dan H. (2018). Desain Game Edukasi Berbasis Android pada Materi Logika Matematika. Jurnal Nasional Pendidikan Matematika, 2(2), 165-179.

Pribadi, B. (2011). Model Desain Sistem Pembelajaran. Jakarta: Dian Rakyat.

Sadiman, A. S. (2014). Media PEndidikan. (Sinwari Natakusumah, Ed.). Jakarta: Pustekkom Dibud dan PT RAJA GRANFINDO PERSADA.

Sani, R. A. (2016). Inovasi Pembelajran. Jakarta: Bumi Aksara.

Trianto. (2014). Model Pembelajaran Terpadu Konsep, Strategi,dan Implementasinya dalam Kurikulum
Tingkat Satuan Pendidikan (KTSP). (F. Yustianti, Ed.). Jakarta: Bumi Aksara. 